\title{
THE DIASPORIC ISLAMIC MASCULINITY AND THE REFORMULATION OF EUROPEAN ISLAM: THEORETICAL APPROACHES AND INTERPRETATIVE PERSPECTIVES
}

Valentina Fedele

Università della Calabria

http://dx.doi.org/10.5209/rev_NOMA.2013.v40.n4.48341

\begin{abstract}
.-
Diasporic Islamic hegemonic masculinity is rarely analyzed in both sociology and gender studies, and, if addressed, it is generally linked to phenomena of deviance, not considering the religious as one of the constitutive elements, non-reductionist, but autonomous, of contemporary Islamic masculinity.
\end{abstract}

Based on the issues raised during a doctoral research implemented among diasporic Muslims of North African origin in Italy and France, the article proposes to reverse this perspective, placing the process of construction of diasporic Islamic masculinity in the wider context of the reformulation of European Islam, using a transnational approach and following social-constructivist gender studies.

This perspective allows to some highlight elements useful for the understanding of the dynamics underlying the construction of masculinity in contemporary Islamic Mediterranean identifying possible path and directions of recomposition.

\section{Keywords}

Islamic masculinity, European Islam, transnational approach; Mediterranean studies.

\section{Introduction}

Analysis on Islamic masculinity are rare in sociological and gender studies. In the last decades a tradition of academic and scientific analysis on Islamic femininity and the role that religion and interpretation of sacred texts has in its definition has been developed, both to denounce Islamic inherent sexism and discrimination, and, as in the case of socalled Islamic feminism, to highlight its potential for emancipation. Moreover, those analysis concerning Islamic masculinity, generally, take into account religion only with respect to marginalized groups, for example because of sexual orientation, whose marginalization is religiously legitimated, especially in traditionally Muslim countries. (Kugle and Hunt, 2012; Murray and Roscoe, 1997) ${ }^{1}$.

\footnotetext{
${ }^{1}$ Exceptions are those studies on masculinity in pietistic Islamic movements (Geoffrey, 2011; Metcalf, 1993). At the time of writing the article, the author acknowledges two works dedicated specifically to Islamic masculinity, Lahoucine Ouzgane, Islamic Masculinities, 2006 and Ghoussoub and Sinclair -Webb, Imagined Masculinities, 2000. It has to be underlined that studies on religious masculinity in general are also rare within masculinity studies, in particular those recognizing religion as a constituent of gender identity. In this case, as Kimmel (2012) emphasizes, often reference to religion is involuntary or can be reconstructed, as for example in Weber, given the tendency to describe the whole humanity as male.
} 
The masculinity that Connell (1995) defines as hegemonic ${ }^{2}$, instead, is rarely investigated, if not linked to phenomena of violence, social exclusion and terrorism, or at least conceptualized as deviant masculinity (Amar, 2011), often considering Islam not as one of its constituents, but as a causal problem. Thus, paradoxically, as emphasizes by Ruba Salih (2008), Muslim women, considered excluded from the public sphere are at the center of political, religious and social narratives, while hegemonic masculinity, considered the main subject of relevant political and social dynamics, is not discussed perpetuating its same dominance (Dialmy, 2009; Ouzgane, 2006).

This perspective is replicated in the studies concerning Islamic masculinity in Diaspora, where the analysis of Islamic masculinity as deviant is accompanied by a public discourse constructing Islam as the difference par excellence, the negative of the characteristics of national identity, in the European case and in continuity with colonial dynamics, projected on males coming from traditionally Muslim countries and, in particular, from North African and Middle Eastern Arab countries, overlapping the actual religiosity and the characteristics of those involved.

The article analyzes how Islamic religious is involved and acts, along with other factors, but autonomously, in the multidimensional, complex and transnational process of definition of Islamic diasporic masculinity, placing it within the dynamics of consolidation of European Islam, focusing on the analysis of the subjectivity of Muslim males of North African origin, with particular reference to the so-called second generations, in Italy and France. ${ }^{3}$

It is necessary to emphasize that, however, the religious does not exhaust the possible personal belongings of people coming from Muslim majority countries, both because religious belief and, therefore, its re-formulation, has a strong personal feature that subdivides its possible expressions, making difficult to offer generalizations inclusive enough, and because assuming Islam as a constituent axis of construction of gender subjectivities and models, excludes all those people that while recognizing themselves as part of a system of values generally attributed to Muslim world, do not consider religion as a reference or a necessary attribute of their idea of masculinity, placing themselves outside the same building of a religious narrative, such as the so-called cultural

Muslims ${ }^{4}$.

\footnotetext{
${ }^{2}$ Hegemonic masculinity in Connell's meaning, refers to the process by which certain groups are in power and determine, for this reason, the socially dominant form of masculinity in a culture in a given historical period, legitimizing patriarchy in local practices and gender social stratification, acted outward towards to women and inwards towards other men, lacking social and economic resources to participate hegemonic masculinity. See Connell (1995, pp. 77-82).

3 The article is based on the results of a wider doctoral research analyzing the reformulation of Islam in the European diaspora that between 2009 and 2012 has involved 60 Italian and French Muslims whose families came from Algeria, Tunisia and Morocco.

4 Statistics on Muslim population in Europe are mostly indicative, complicated by many factors, including the difficulty of collecting data on ethnic or religious basis, addressed differently in different countries: in some - such as France, Belgium, Denmark, Italy and Spain - there are constitutional or legal barriers, laws on privacy and on protection of sensitive data, in others - Austria, Estonia, Finland, Germany, Ireland, Slovenia and the UK - exceptions to the rule are allowed on the basis of voluntary participation in the census, and in others - such as Germany and Sweden - the same religious communities provide data on believers. Moreover, it is discussed the same definition of European Muslims: generally all the people coming from Muslim majority countries are considered Muslims - ascribed Muslims (Dassetto, 2009), sociological Muslims (Allievi, 2002), susceptibles d'être musulmans par filiation (Tribalat, 1995) - the
} 
Despite being a minority within European Islam, those religiously active are also those participating at the reformulation of the Islamic religious discourse, of what Berger (1994) calls structure of plausibility of Islam in a minority context; therefore, they affect the very definition of contemporary European Islamic masculinity, building models and negotiating them within the public space, with respect both to European society and to communities coming from traditionally Muslim majority countries, contributing on the one hand to deconstructing post-colonial stereotypes and prejudices, on the other to answering to what Ventura (2009) identifies as the long-standing identity crisis of the Muslim world, as a universe of sense, regardless of its spatial references.

Taking into account the transnational horizon within which the process of definition of European Islam unfolds, the article addresses both the religious and the socio-cultural elements associated with Maghreb Islamic masculinity, as well as the consequences of the peculiar conditions of reworking Muslim creed in Europe, in order to detect the main features of re-negotiation of gender experience in diaspora and the circularity of Islamic models of masculinity.

The study of Islamic diasporic masculinity in the social-constructivist perspective The identification of the procedural nature of a dynamic model of European Islamic masculinity lays in continuity with the social-constructivist approach to gender, whose point of departure is that, as underlined by Ouzgane (2006, p 2), 'men are not born, they are made within particular social contexts '.

This approach, especially in its more recent developments, recognizes the variability of the concepts of masculine and feminine between society and society and, in the same society, between different historical periods and in the same society in the same historical period, between generations, and in the same society, in the same historical period and in the same generation, between different social, economic and cultural groups (see Kimmel, 2000; Connell, 1995; Connell and Messerchmidt, 2005). These evidencies were particularly enriched during what Connell (2012) calls the ethnographic moment of masculinity studies, that in the 90s saw the production of numerous empirical studies, documenting different models of masculinity, in different cultures and social spaces, emphasizing the multifaceted nature of the definitions of masculinity, locally and globally, drawing attention to the need for new conceptualizations, able to read the variability of expressions of the same hegemonic masculine subjectivity, deconstructing elements that, highlighted in the study of white, Western and bourgeois masculinity, were often regarded as universal. New studies, then, have focused on the multiplicity of male models living in the same social space, constructed and relevant with respect to marginal and marginalized groups, not necessarily because deprived of desirable features for the dominant male models for example, because of scarce economic resources or different sexual orientations - but because they possess other characteristics, specifically cultural or ethnic, questioning

number of whom can be reduced by the percentage corresponding to religious minorities in the country of origin. This choice, however, do not take account Muslims born in the host countries, often three or four generations later, holding, mainly, a European nationality, nor converts. None of the statistics counts, the actual belongings and the practice of European Muslims. Considering these problems, Muslims in the European Union can indicatively be estimated as about 16 millions, of which, according to geographically and numerically limited polls, religiously active people are between one third and one fourth (Dassetto, 2003). 
mainstream interpretations of the same concept of hegemonic masculinity (Demetriou, $2001)^{5}$.

Marginal groups, therefore, built, precisely on the basis of these characteristics, concepts of masculinity dominant to the group, but marginal to the hegemonic model, which not only can not aspire to be part of it, because of their cultural characteristics - although, like other subordinate masculinities benefit of the patriarchal dividend, the tangible or intangible benefits coming from the action of hegemonic masculinity to the outside - but built in opposition to it, rejecting or exasperating some of its traits. Although recognizing the possibility of coexistence of different expressions of masculinity, these approaches often perpetuate the dualism hegemonic/subordinate masculinity, emphasizing the oppositional nature of the relationships between them, lacking to recognize the existence of models that, subordinate to hegemonic masculinity while sharing with it some attributes - like heterosexuality - have other characteristics considered desirable and therefore necessary to a particular group and missing to the hegemonic model.

In the analysis on masculinity directly or indirectly linked to migration, such duality can be overcome by using a transnational approach, considering, therefore, as part of the construction of gender subjectivity and patterns, not only the dynamics of comparison with hegemonic masculinity produced by dominant group in a given social space, but also the concept of masculinity dominant in communities' countries of origin, and the resulting hybrid interaction and mutual acculturation between them. In the article, the use of a transnational approach is ensured by the very definition of European Islamic masculinity as diasporic, assuming the word diaspora in the sense of Peter Mandaville (2001) ${ }^{6}$ in his work on the reconstruction of Muslim community of believers - umma - in transnational spaces. The author, indeed, defines as diasporic those people whose families have moved in the past three generations between significantly far countries, maintaining a relationship with them, remembering them and, as a result, taking them through the experience of travel.

From this point of view, therefore, the idea of Islamic masculinity, as all the ideas travelling in transnational spaces, is built through the interaction of models of masculinity, both hegemonic and subordinate, of the original countries, of the travel experience itself, of the subordinate and hegemonic masculinity of the social space to which communities have moved, in this case Europe, of the social and cultural conditions that have produced and continue to produce them, of the subjectivities involved in the reformulation of masculinities, and finally, of the circular relationship between the idea and all the parts of the interaction described.

\footnotetext{
${ }^{5}$ According to the author, Connell considers not hegemonic masculinity completely passive in the process of constructing hegemonic masculinity, that is always white, western, rational, individualistic and heterosexual, while subaltern masculinities are described as possible alternatives of resistance that do not affect the dominant model. Marginal groups, instead, actively participate in the construction of the hegemonic model, exercising resistance to subordination, generating definitions of masculinity that become part of hegemonic masculinity through complex forms of negotiation. Following this critic, the study of Inhorn (2012) on contemporary Arab masculinity in the relationship to infertility, proposes to replace the concept of hegemonic masculinity with that more dynamic of emerging masculinity, based on the categories dominant, residual and emergent conceptualized by Raymond Williams in its analysis of social classes. See Williams (1973).

${ }^{6}$ In developing this definition, Mandaville recalls directly the Greek root of the word diaspora and its original meaning of dispersal of seeds.
} 
Circularity acquires a special value when considering the area of North Africa and Southern Europe, an area experiencing a typically Mediterranean transnational dimension, characterized, as pointed out by Braudel (1987), by "rivalry, hostility and mutual acculturation" (ivi: 102, T.d.A), as well as by "sacrifice, irradiation, accumulation of cultural heritage, inheritance of intelligence" (ibid: 112, T.d.A.), an hybrid space, that, as such, fully frames Islamic religious phenomenon.

Islamic diasporic masculinity is configured, then, not as a static model, but as a symbolic repertoire and a dynamic significant, whose traits and characteristics can be activated, emphasized, marginalized, dismantled and reconstructed by European Muslims depending on spatial, historical, social, temporal and personal circumstances. The emphasis on the religious adds a distinctive feature to the analysis proposed.

The reconstruction of identity based on religion, in fact, involves an element, Islam, which is generally excluded from the characteristics of hegemonic masculinity. European national identities and powerful groups, in fact, consider secularism and religious privatization as founding characteristics, excluding religiosity tout court from hegemonic male models' traits, particularly when, as in the case of European Muslims, it is a religious minority, whose difference has often reinforced the same construction of European identity (Leurs, Midden and Ponzanesi, 2012).

Islam, however, is an active part of the reconstruction of the diasporic subjectivities considered, despite being excluded from the traits of hegemonic masculinity, generating a reworking dynamic that it is not an oppositional process, but a creative one, at the same time challenging and borrowing hegemonic traits, religiously justifying their relevance, bargaining them also with cultural and communitarian elements, whose relevance or marginality is also linked to the religious discourse. The issues involved in this process are manifold, but approached from the religious point of view, they reveal a line of continuity in the Mediterranean, ranging from the Revelation to contemporary masculinity, passing through some socio-historical break points, in particular the colonial experience.

\section{Masculinity in the Islamic Revelation}

The starting point of an analysis considering the religious as the center of the reconstruction of gender identity is the concept of gender in religion as revealed, in the case of Islam, then, the analysis of gender concept in Qur'an and the Sunnah, the collection of hadith, sayings and acts of the Prophet Muhammad. In Islamic theology, God is beyond the concept of male and female, as demonstrated by its attributes, holding male and female traits, constituting a Unit, tawhid, which includes the duality and the dialectics between two complementary poles male/female ${ }^{7}$. These two elements become characteristics of the human beings, following paths of differentiation institutionalized by the Qur'an itself, that, together with Sunnah, traces specific lines of demarcation between men and women, whose position is expressed as

\footnotetext{
7 The best known names of God - al-Rahman and al-Rahim - the Gracious and Merciful, embody feminine characteristics that dominate all the others within the Islamic idea of God. Concerning biographical account of the Prophet, the first best known in literature is the collection of essays of the Indian reformist Sayyid Ahmad Khan (1870), conceived as a critical response to the Orientalist visions of European scholars, thus structured in a defensive optic (Ouzgane, 2006).
} 
equal with respect to the acts of worship - ibadat - and therefore in the religious, but different, complementary, in social acts - mua'malat - in the public and private sphere, as well as in the aesthetical and behavioral one ${ }^{8}$. As it is often represented, complementarity is a triangle whose apex is God, with respect to which men and women are on the same base but on two different angles, complementary indeed. The institutionalization of the differences between men and women has led, since the Revelation, scholars of Texts and law schools to identify ethical, moral, aesthetical and behavioral patterns to norm religiously oriented expression of masculinity and femininity. A particular emphasis in the reconstruction of masculinity norms has been placed on the Prophet himself, which, along with Abraham, fully embodies the fitra, the nature of God in which every human being is created in perfection and beauty ${ }^{9}$. In particular, Muhammad is considered al-insan al-kamil, the perfect human being, and uswa hasana, the excellent model of conduct, which sublime morality, religiously and ethically is an example for all the believers, both men and women, but, for the same fact of being male, is a special reference for Muslim masculinity construction, that, in this way, follows a common religious continuity. In this sense, has to be understood, for example, the insistence on hygienic, aesthetical and cosmetical practices, part of Sunan al-Fitra, a set of behavioral norms, recommended but not mandatory, based on the example of the Prophet, as well as the spreading of the collections of testimonies on the life of Muhammad, focused on daily actions and intimate and emotional relationships, both building a model of perfect Muslim (2006).

The characteristic features of this model, on which historically have been superimposed cultural elements, sometimes becoming part of the very religious tradition - such as circumcision $^{10}$ - have formed a set of rules, continuously revised, often following not so much the Sacred Texts and their requirements, but the contingent historical and social needs, making religion a tool of resistance to or legitimacy of patriarchal power in the name of Islam (Ouzgane, 2006).

\section{Colonialism and the construction of North African Islamic masculinity} One of the historical and social events particularly relevant to the contemporary reworking of masculinity Islamic colonialism.

Despite the diversity of individual national experiences ${ }^{11}$, colonialism was accompanied by a gender narrative, which had significant impacts on the pre-colonial subjectivity, as, indeed, the entire project of orientalization of the East, described by Said (1991) that, as Ruba Salih (2008, p 14 T.d.A.) underlines, "is certainly a cultural construction [... ] but it is also a sexual fantasy built on sexual difference".

Gender discourse, in fact, has been a central element of the attack to local population memory, history and culture, since the Napoleonic expedition to Egypt in 1798, founding

\footnotetext{
${ }^{8}$ See Qur'an 49:13; 4:1.

${ }^{9}$ See Qur'an 30:30; on the immutability of God's creation cfr. Qur'an 35:1, 40:64; 64:3; 95:4.

${ }^{10}$ Circumcision is a practice not mentioned in the Qur'an, little discussed in the hadith and considered mandatory by only one of the four Islamic classical legal schools. Nevertheless, it was built in the public discourse as the religious rite of masculine differentiation by definition, the sign of Islamic masculinity linking fathers and sons (Crapanzano, 1981; Lagrange, 2008).

${ }^{11}$ As for the area considered, Tunisia and Morocco were French protectorates respectively since 1881 and since 1912 to 1956; Algeria was under French colonial rule between 1830 and 1962, while Egypt was under British administrative and military supervision from 1882 to 1936 (except for the Suez Canal). For a broader historical analysis see Mansfield (1993, pp 164-258).
} 
future colonial expansions. Gender metaphors accompanied the construction of the Eastern other, justifying the Western attitude towards East, often built as an irrational, helpless woman that the West, with its supposedly masculine qualities of strength and logic, had the task of driving.

As emphasized by Dialmy (2004), colonial experience has deconstructed Maghreb traditional socialization, typically based on the distinction and standardization of two different sexual identities, through hierarchical rituals and social practices, supported by religion - rites of birth, marriage and childhood games - where hegemonic Muslim masculinity occupied the main space especially in the public sphere, acquiring powers and privileges because of two fundamental elements, being man and being Muslim. The both, however, are challenged and destabilized by colonialism that, as described by Fanon (1986), undermines their foundations, questioning the honor of North-African society, threatening women, discussing the capacity of men to protected them. Colonialism, in fact, constructs a narrative in which North African males are reduced to children or animals, brutal and incompetent, opposed to the colonizer male, powerful and rational (Fanon, 1986; Siebert 2012); at the same time, it deconstructs the desirability of being Muslims, the religious center of pre-colonial hegemonic masculinity, attacking the entire Islamic universe of sense, described as determining the unsurpassed state of inferiority of local populations ${ }^{12}$.

In this discourse, as Renate Siebert (2012) emphasizes, two worlds constructed substantially as masculine are compared, Muslim women becoming part of the same justification of colonialism, through the rhetoric of the necessity, to which the rational West answers, to emancipate them, to free them from the alleged sexist yoke of Islam, to unveil them ${ }^{13}$ : in this way the internal resistance has been affected, attacking what is considered as the symbolic centerpiece of the colonized societies, that is the family. As a result, from the point of view of North African populations Islam and the religious become an outpost of resistance, the unique, authentic and inviolable banner of the nation and the family, leading to an over - investment on Muslim man image, recovering many elements of the Sunan al-fitra, such as the provisions in the cutting of the beard, as well as the classical gender roles within the family, the relationship religiously established, reinforcing and sometimes petrifying traditional patriarchal gender differences (Siebert, 2012).

The latter remain central also in the narrative of the independent States, where the religious structures the discourse of legitimation of a power that, within the colonial boundaries of space and time, was being built as masculine, urban and patriarchal, despite the struggles for independence had deconstructed in colonial and pre-colonial assets $^{14}$.

\footnotetext{
${ }^{12}$ As pointed out by Connell and Messerchmidt (2005, p 75) colonial power builds his narrative on the superiority of colonizeds, emphasizing racial and cultural differences, and determining on the latter a state of inferiority, reinforced by a gender discourse: "gender ideology tended to fuse with racism in forms that the twentieth century never untangled (....) the imperial social order created a scale of masculinities as it created a scale of communities and races".

13 The urgency to unveil women (Salih, 2008, p 14) is still the center of post-colonial discourses on democracy and liberation, as evidenced by those accompanying, for example, military intervention in Afghanistan.

${ }^{14}$ New models of hegemonic masculinity based on urban nationalism, as Jamal Abdel Nasser in Egypt, lived together with new emerging and properly Islamic masculinities, based on literalist religious reformist movements, embodied by Hasan al-Banna in Egypt and Ali Belhaj in Algeria. Many of the features of these models persist nowadays, despite the variety of the axes of recomposition of male Muslim identity.
} 
Islamic masculinity and the construction of the difference Islam in Europe Part of the colonial rhetoric described, in particular regarding the dynamic of construction of the difference Islam based on the stigmatization of masculinity, is central to the contemporary definition within the European public sphere of Islam, considered, without socio- demographic distinctions or internal differentiations as the fundamental marker of people coming from a Muslim majority countries or Arab countries in general. The construction of the difference Islam uses, indeed, gender discourses that have a particular impact on the process of definition of Islamic diasporic masculinity. Islam has become the central element in the European public debate, marking the construction of the other and overlapping further distinction elements, embodying the primary and irreconcilable diversity in the European area. Such a discursive construction involves, among other things, an overinvestment on religious in the construction of what Roy (2009) calls the invented neo-ethnic group of European Muslims. European society with its institutions and narratives, ethnicizing the religious category to indicate people coming from or whose families come from Muslim-majority countries, is crucial in the creation of European Muslims, making the religious tract, allegedly shared, the lowest common denominator unifying people from different places with different languages, cultures, experiences (Roy, 2009).

As a result, as pointed out by Leurs, Midden and Ponzanesi (2012), a double dynamic circulates around Islam: on the one hand, every member of the group is seen firstly and foremost as such, and acts accordingly; on the other society treats any alleged member of the group as belonging to it, expecting predetermined actions and discourses. This process, useful also to the will of European political and social institutions to structure and institutionalize Muslim communities in the area, puts the religious at the core of the relationship between diasporic Muslims and European society, reactivating the symbolic heritage of the religious, in the construction of boundaries of belonging, of communitarian and social definitions of identity, often beyond the actual adherence to Islam itself.

At the same time, however, European society is involved in the bargaining and in the reformulation of the repertoire of meanings and narratives that have to constitute European Islam, which alleged believers are expected to act their religiosity in a certain way, with respect to which, deviations are usually reduced to the survival of cultural practices or to social deviance. Thus, as Leila Babes (2000) emphasizes, this creates a homo islamicus, out of time and space, for whom professing Islam is a sign of lack of integration, not professing a sign of identity problems.

in parallel, in continuity with colonial rhetoric, this narrative replicates gender stereotyping that builds males as the negative pole of the Islamic community, especially when young, and, therefore, typically belonging to the so-called second generations. This perspective has been consolidated in a securitarian optic - after a series of international political events such as the attacks of September 11, 2001, and those in Madrid in 2004, and as a result of social conflicts, that while not having a directly religious character, have been traced to an inherent non integrability of Islam, as in the case of the riots of the French banlieues ${ }^{15}$.

15 This approach is reflected in a peculiar way in the American literature on masculinity, that, as pointed out by Kimmel (2000) Muslim men, superimposed on Arab men, are constructed in the public discourse as 
The combination of the religious and gender stigma, in this way, involves in the social practice a generally more positive attitude towards Muslim women than Muslim men. Although analysis often detect a double discrimination against Muslim diasporic women, as women and as Muslims, especially when adherence to religion is expressed through the hijab, in general, they tend continuing to be perceived as victims of religious patriarchy, supported instead by men, violent, criminals, vicious or stupid (Frisina 2007). This social stigma contrasts with communitarian and familiar narratives that, often replicating patriarchal cultural codes religiously informed, as a way to assure a continuity with migration projects, invest more on the social success of males, producing expectations are sometimes disregarded just because of the imagery built around the Muslim males in the European public sphere.

The double bargaining - with the society on the one hand and the community on the other - influences the production of Muslim dominant masculinity, especially considering the role that Islam plays in the same bargaining, in particular the reformulation of Muslim religiosity as a desirable element, as a resource of the hegemonic model in the face of its marginalization and social stigmatization.

Nevertheless, it does not exhaust the elements that influence the definition of Islamic masculinity, among which are relevant the broad forms taken by the reformulation of diasporic Islam within the European socio-religious space.

\section{The reformulation of European Islam}

The main characteristic of contemporary European Islam is that it is a minority in a plural and pluralistic context (Cesari, 2004) ${ }^{16}$, accompanied by a marked internal pluralization, linked to the process of de-ethnicization, mostly resulting from the lowering of the ethnic threshold (Allievi, 2002) due to the progressive heterogenization of migration flows. Within the European Muslim community, therefore, coexist multiple languages, multiple ways to experience and feel the religious, multiple traditions ${ }^{17}$ that, on the one hand, highlight the natural diversity of Islam, deconstructing monolithic images, on the other generate the comparison between different interpretations and practices, in order to establish which of these derive from local cultures and which are properly religious.

opposed to American men in a dialectic good/bad, that tends to the feminization or to hyper-masculinization of its negative pole.

\footnotetext{
${ }^{16}$ From the historical point of view, being a minority Islam is not new: as an example, the experience of the Tatars in Russia from 1522, the Mudejar in Spain from 1552 till the beginning of the seventeenth century, as well as experiences not ascribed to conquests, as those of the Chinese Hui, the Muslims of Cambodia and Thailand, and those who have decided to stay in India after 1947 (see Roy, 2003, p 46-47). The difference in this case is that the minority status derives from a voluntary movement of the Muslim population, usually from countries where Islam is the majority to countries where it is not. From the sociological point of view, the majority position in Islam has always been considered as a fact: it is not a coincidence that Islam places its date of birth from hijra from Mecca to Medina, when Islam became (Allievi, 2002). European Islam, although predominantly originated from a migration, a hijra, is in a Meccan condition, as it is a religious community among others, exposed to a pluralism that affects not only the religious feeling, but also the culture and society in general.

17 This character, that Allievi defines ummic, concerning the plurality inherent to the islamic concept of umma, was progressively lost in traditionally Muslim-majority countries in the context of National and nationalist states, but it is enhanced in European Muslim communities by the characteristics of contemporary migrations and the consequent lowering of the ethnic threshold.
} 
This comparison and its results emphasize a process that concerns contemporary religious in general, but is particularly evident in migrant communities that Roy (2003; 2009) calls deculturation.

Islam, thus, is separated from the cultures of origin, conceptualized as a subject separated from the social practice, re-formulated as a pure religious, on the base of its Sacred Text, freed from cultural and traditional readings and interpretations. This process reflects also the separation between Islam and the territory that Allam (2002) identifies as the original feature of European Islam.

Deterritorialization involves the lack of a centralized organization of religion, and of legal, social or cultural constraints to religious, as well as of authorities legitimized by a superordinate structure to identify with. Being a Muslim becomes, therefore, a choice of belonging both at individual and collective level, a virtual reality to imagine and to construct, out of traditional constraints.

Those features affect both collective reformulation of some Muslim symbolic fundaments, and beliefs and behaviors of the individuals.

One of the most interesting issues of the reformulation of deterritorialized Islam is, in fact, the reconstruction of the umma, the social fact of definition for Muslims, the space of the recognition and the construction of otherness in the universal sign of God's word (Dassetto, 1994). This universal meaning has been accompanied, after the hijra from Mecca to Medina, and even more after Prophet's death, by an historical significante, identifying the umma as a social, political and geographical body. Only after the abolition of the Caliphate in 1924 the umma found itself freed from political and moral authority of reference, and acquired a strong identity value in the colonial period in the reformist discourse, both as an anti- Western and as an anti-regime tool. The political dimension and territorial cohesion of the umma inevitably fade in the context of European Islam, as in minority post-migration contexts in general, engendering its reformulation according to new categories (Allam, 2002). Umma, thus, develops two main dimensions: on the one hand a virtual dimension, as a universal, transnational community of faith that unites all those identifying themselves as Muslims (Roy, 2003); on the other a local dimension, as a concrete and visible community, with respect to which manifesting the choice of belonging to Islam (Dassetto, 1994). The transnational umma, a de-territorialized space lacking traditional structures of monopoly is also an arena in which different parties compete to articulate the meaning of Muslim creed, trying to answer the demands of adapting it to a minority situation, to establish what is Islamic and what is not, what are the characteristics of European Islam and of contemporary Islam in general. On the side of personal beliefs and practices, the main characteristic of European Islam is its progressive individualization, which in this case is "a dramatic re-location within a society has fundamentally already led this process to an advanced stage " (Allievi, 2002, p 148, T.D.A.) that emphasizes direct relationship with God and the discovery of principles that precede and exceed the same religious practices. Although Islam, as pointed out, is a religion embracing social and daily issues, it emphasizes also the direct relationship between God and man and the importance of faith, iman, whose sincerity and depth is only known by God.

The diasporic deterritorialization emphasizes this aspect, leaving Islam orphan of its traditions and its classical central authorities, resulting in the contraction of the legal 
form, enlarging the space of personal and internalized spirituality (Roy, 2003). Spirituality, thus, is declined in the emphasis on direct relationship with God and in the commitment in the pursuit of personal salvation, but also in the individualization of the meanings, manifested with the attitude defined by Roy (2003, p 78) à la carte, taking from orthodoxy only what it is necessary to fulfill own needs.

On the other hand, deterritorialization also causes the weakening of the normative dimension, resulting in the loss of social constraints and cultural traditions, as well as that of legal certainty linked to the organization of religion by centralized states (Roy, 2003). Reformulation of Islam as purely religious in a context in which legal forms are contracted, leads to emphasize the ethical and moral dimension of the message (Allam, 2002), transforming Islam as a possible way of life. This enhance the importance for believers of expressing their chosen religious belonging not only through practices, but also through social behavior and aesthetic appearance.

The emphasis on the ethical dimension is also functional to the needs of modernity: following the analysis of Berger, Dassetto (1994) points out that the uncertainty inherent to modern situation imposes the need for a daily organization of time, a structuring of time and space. In religious terms, this need is met by practices and rituals with their repetitive nature: specifically Islamic orthopraxy that itself occupies precise spaces and times in believer's everyday life, takes on a special meaning in the situation of pluralistic and pluralized modernity. The social behavioral dimension, in this sense, fills the spaces left empty by rites, giving a constant sense to musulmanity, expressed not only in each action performed, but also in exteriority. Mu'amalat, social religious acts, take on, as a consequence, a marked ethical character.

The processes described are emphasized in the case of so-called second generation, properly diasporic Muslims, often subjects of the same negotiation between communities and society, as in their case the whole or large part of their socialization takes place in Europe and deterritorialization, deculturation and de- ethnicization are given facts, more than processes.

Second generation diasporic Muslims have a peculiar relationship with European society, that Allievi (2002) sums saying that while their parents are Muslims because Egyptians or Moroccans, sons and daughters are Muslims because they are neither Egyptian nor Moroccans: they are born again Muslims, choosing to be an active part of the project of reformulation of Islam beyond linguistic, national and cultural issues (Roy, 2003). For this reason, they affect in a particular way the process of construction of European Islamic masculinity, developing new models, re-articulating features, on the base of the Sacred Texts, as the entire reformulation of diasporic Islam, borrowing elements of both the masculinity of the countries of origin, and of the European hegemonic model.

\section{The Construction of Masculinity among the European diasporic Muslims: interpretative perspectives}

The characteristics of the reformulation of Islam in diasporic context and the consequences they generate in subjective beliefs and practices - individualization and emphasis on ethical and behavioral dimension - as well as in collective forms - resignification of the umma and multiplication of the subjects of the sacred - enable a reading of the process of reformulation of European Islamic masculinity from a purely 
religious point of view, highlighting features missed by a dualistic and oppositional analysis.

As underlined, building own subjectivity on the Quranic norm Quranic and the Sunnah, taking into account the lack of legitimate authorities and of a centralized interpretation, determines a constant search for the definition of what it means to be Muslim, sustaining the differentiation of the possible interpretations: the multiplication the subjects speaking in the name of Islam fragment, indeed, the interpretive authority and democratizes the reading of the Sacred Text.

This fragmentation, along with the emphasis on the direct relationship with God and on the religious subjectivity, should lead to a greater flexibility in the Islamic concept of masculinity, in which, should co-exist different elements, even in conflict between each other, all equally legitimate from the point of view of religion, that believers should refer to depending on own religious sensibilities. This proposition, however, it is partially real, only as it pertains to the co-existence of multiple subjective significations, because they are all rooted in a single model, religiously normative, based on Sacred texts thus defining strict boundaries.

The choice to be Muslims, in fact, reformulating purely religious requirements contained in the Sacred Texts enhances the recovery of elements developed in the early centuries of Islam, re-evaluating the classical model of Muslim male traced back to the Prophet, to an original experience whose consistency is sanctioned by the very words of God. This model, in European Islam, in a deterritorialized context of minority, cannot be reelaborated as dominant within a public sphere that stigmatizes Muslim belonging, so it is re-elaborated in an ethical, aesthetical and behavioral sense, and in the private sphere, which privileged place is family.

In the interviews realized with North African diasporic Muslim male in Italy and France, these two elements are central to the elaboration of being male and Muslim: being a Muslim man means to have faith, but also adopt an Islamic way of life expressed through participation to religious practices, but also in the public sphere by demonstrating an Islamic behaviors and acting an Islamic moral. The latter determines an attitude of interest and participation, religiously informed, to the surrounding world: being a Muslim man means being good to neighbors, generous to poor, welcoming travelers, being socially responsible, working and not wasting money, holding a healthy lifestyle, respecting human life, addressing conflicts through dialogue, keeping promises, being honest and productive. The aesthetic also gains importance, according to personal sensitivity, as a means to BE recognized as a Muslim man, once again emphasizing the significance of the beard, but especially the prophetic prescription, according to which a man must be aesthetically different by a woman.

Family in this discourse becomes the privileged place of expression of own male subjectivity: from this point of view, Muslim men have not commit adultery and fornication, have to hold an appropriate attitudes to women especially in mixed environments, to respect parents, to act as fairly good head of the family with children and the wife.

Concerning the latter, the interviews reveal a widespread preference for religiously endogamous marriage, preferably with diasporic Muslim women, in order to complete own spiritual growth, conceived as part of a religious project that from individual 
becomes familiar. The wife is imagined or described as a person who is studying and working, expressing herself in the public and in the religious sphere, but also in the private one, raising children, taking care of the house, supporting her husband in his choices.

The ethical, aesthetical, behavioral and familiar norms thus become the basis for the construction of a dominant Muslim masculinity, on the one hand benefiting from hegemonic patriarchal dividend, as males, on the other creating properly Islamic hegemonic models, resulting in religious patriarchal dividend that, as such, is expressed inward and outward.

The Islamic model of masculinity, however, irrespectively of its characteristics and of the recognition of the subjectivity of believers' individual paths, has a limit in the fact itself of originating in the religious, of being built on the word of God, an unchanging basis, despite different interpretations.

Although it is an open and dynamic model, constantly being redefined its attributes are more difficult permeable to cultural changes that can overthrow perspectives of the hegemonic model, precisely because they are rooted in the Sacred. The major challenges to contemporary Islamic masculinity therefore, arise from within, from the relationship with patterns of Muslim male that while emerging in the same European public space, contradict dominant features, both those shared with hegemonic masculinity - for example heterosexuality - and those properly Islamic. In addition, the expression of masculinity in relation to Muslim family proposes, in a deterritorialized and de-cultured context, the re-articulation of the two classical poles of Muslim hegemonic masculinity, that are being male and being Muslim.

The model proposed in the interviews, in fact, not explicates the revival of pre-existing patriarchal structures, but puts them in dialogue with hegemonic corresponding elements, religiously endorsed: in particular, from the descriptions of the ideal or real wives and family relationships, arises implicitly the classical idea of complementarity between man and woman, playing different and pre-established roles within a common religious project that tends towards God.

One final thought comes from the peculiar transnational dimension of the discursive space of the umma.

As underlined the reformulation of Islam acts in a religious sphere described by Mandaville (2001) as a middle public sphere in which are expressed both the instances of the middle classes of countries of origin and those of diasporic communities, contributing to the dialogue, the movement, the interaction and the construction of deculturated ideas and models, to be bargained with local communities, encouraging the emergence of common constituents (Eickelman and Anderson, 1999, p 9). The main media through which Muslim public sphere express itself are satellite television and the Internet, the latter being the de-territorialized medium par excellence, the best place for the reconstruction of the imaginary umma, accompanying at the same time the process of individualization of beliefs: despite the exchange of information takes place in a virtual community, with more people attending, internet access remains individual, leaving the individual believer to interact and express his subjectivity, selecting the information he needs (Eickelman and Anderson, 1999). 
Transnational dimension of communication facilitates the circulation of deculturated models of Islamic masculinity processed in different geographical areas, supporting their mutual acculturation.

From this point of view, European Islamic masculinity is in continuity with the new transnational and globalized masculinities described by Kimmel (2010). The author argues, indeed, that globalization changes the construction of masculinity, renewing the arena in which national and local masculinities are articulated, reconfiguring traditional, neo-colonial, economic, political and cultural structures, challenging domestic and public patriarchy ${ }^{18}$.

Specifically, the European Islamic masculinity, circularing within the Mediterranean, influences and is influenced by events that, on both sides, can support the emergence of new models and discourses: in this sense the future forms of diasporic Islamic masculinity are likely to be affected by new masculinities emerged from the Arab uprisings of 2010/2011, defined by Inhorn (2012) as protest masculinities, for long time concealed by authoritarian regimes, that have found a special place in the digital Muslim public sphere.

\section{Concluding remarks}

Focusing on Islam and its re-formulation as the center of the study on Islamic masculinity in general and on diasporic one in particular can provide interpretive keys, allowing to detect issues beyond the classical analysis of Islamic masculinity: the revival of the model of complementarity in gender relations, the inherent transnationality of Muslim religious subjectivities acting in the public sphere, the risk related to the re-articulation of the requirements of the Sacred Texts. Religion, in this sense, is understood not as reductionist and ahistorical, but in its becoming religiosity, inserting in a social space, as dynamic and changing.

European Islam is, therefore, part of a more complex interaction leading to the definition of specific masculinity models, not necessarily constructed in opposition to the hegemonic one, but in a continuous relationship with them that involves also masculinity models of Muslim majority countries, as well as properly religious elements and deculturated models, circulating through a public transnational sphere, acculturating each other.

From this point of view, the proposed analysis can also be a starting point to develop tools to read the processes of redefinition of Islamic and not Islamic masculinity in Muslim majority countries, considering them as transnational, as a constituent part in the definition of multiple globalized models, in a continuous tension.

\section{Bibliography}

(2002) ALLAM, Khaled Fouad, L'Islam Globale, Rizzoli,Milano.

\footnotetext{
${ }^{18}$ Kimmel (2010) notes that within this new arena globalized male masculinities are confronted with a global hegemonic model of masculinity that circulates triggering both emulations that resistance to the incorporation, often expressed in nationalists or religious terms.
} 
(2002) ALLIEVI, Stefano, Musulmani d'Occidente, Carocci, Roma.

(2011) AMAR, Paul, "Middle East Masculinity Studies: Discourse of "Men in Crisis" Industries of Gender in Revolution", Journal of Middle East Women's Studies, 7, 3, pp 36- 70 .

(1994) BERGER, Peter L, Una Gloria Remota. Avere Fede nell'Epoca del Pluralismo, II Mulino, Bologna.

1. Cesari J. (2004), Musulmani in Occidente, Vallecchi:Firenze.

(1995) Connell, Raewyn. Masculinities, University of California Press, Berkeley

(2005) CONNELL, Raewyn e MESSERCHMIDT, James W., 'Hegemonic Masculinity: Rethinking the Concept', Gender and Society, 19, pp 829- 859.

(1981) CRAPANZANO, Vincent, "Rite of Return: Circumcision in Morocco". In MUESTERBERGER Warner and BOYER L.Bryce (eds), The Psychoanalytic Study of Society, International Universities Press, New York.

(2003) DASSETTO, Felice, "The Muslim Populations of Europe". In MARÉCHAL, Brigitte, ALLIEVI, Stefano, DASSETTO, Felice e NIELSEN, John, Muslims in the Enlarged Europe, BRILL, Leiden-Boston.

(2009) DASSETTO, Felice, "II Divenire dell'Islam Europeo: Questioni Aperte, alla Ricerca di Buone Pratiche", Religioni e Società, 25, 65.

(2001) DEMETRIOU, Demetrakis Z., "Connell's Concept of Hegemonic Masculinity: A Critique", Theory and Society, 30, 3, pp 337-361.

(2004) DIALMY, Abdessamad, 'Masculinity in Morocco', What about Masculinity 21, pp 104-105.

Eickelman, D.F. e Anderson, J. W. (1999), Redifining Muslim Networks, in D.F. Eickelman e J.W. Anderson, New Media in the Muslim World. The Emerging Public Sphere, Indiana University Press:Bloomington.

(1986) FANON, Frantz, Black Skin, White Masks, Pluto Press, London.

(2007) FRISINA, Annalisa, Giovani Musulmani d'Italia, Carocci, Roma.

(2011) GEOFFREY, Samuel, "Islamic Piety and Masculinity", Cont Islam, 5, pp. 309322.

(2000) GHOSSOUB, Mai e SINCLAIR-WEBB, Emma (eds.), Imagined Masculinities. Male Identity and Culture in the Modern Middle East, Saqi Books, London.

(2012) INHORN, Marcia C., The New Arab Man. Emergent Masculinities, Technologies and Islam in the Middle East, Princeton University Press, Princeton.

(2000) KIMMEL, Michael S., The Gendered Society, Oxford University Press, Oxford. 
(2010) KIMMEL, Michael S., Misframing Men: the Politics of Contemporary Masculinities, Rutgers University Press, New York.

(2012) KIMMEL Michael S. Manhood in America: a Cultural History, New York University Press, New York.

(2012) KUGLE, Scott e HUNT, Stephen, "Masculinity, Homosexuality and the Defence of Islam: A Case Study of Yusuf al-Qaradawi's Media Fatwa", Religion and Gender, 2, pp 254-279.

(2008) LAGRANGE, Frédéric, Islam d'interdits, islam de jouissance, Téraédre, Paris.

(2012) LEURS, Koen, MIDDEN Eva e PONZANESI, Sandra, "Digital Multiculturalism in the Netherlands: Religious, Ethnic and Gender Positioning by Moroccan-Dutch Youth'” Religion and Gender, 2, pp 150-175.

(2001) MANDAVILLE, Peter, Transnational Muslim Politics: Reimagining the Umma, Routledge, London.

(1993) MANSFIELD, Peter, Storia del medio-oriente, SEI,Torino.

(1993) METCALF, Barbara D, "Remaking ourselves": Islamic self-fashioning in a global movement of spiritual renewal". In MARTY, Martin e APPLEBY, R. Scott (Eds) Accounting for Fundamentalisms, University of Chicago Press, Chicago, pp 706- 725.

(1997) MURRAY, Stephen O., e ROSCOE, Will (Eds), Islamic Homosexualities: Culture, History, and Literature, New York University Press, New York.

(2006) OUZGANE, Lahoucine (ed.), Islamic Masculinities, Zed Books, London.

(2003) ROY, Olivier, Global Muslims. Le Radici Occidentali del Nuovo Islam, Feltrinelli, Milano.

(2009) ROY, Olivier, La Santa Ignoranza. Religioni senza Cultura, Feltrinelli, Milano.

(1991) SAID, Edward, Orientalismo, Bollati Boringhieri, Torino.

(2008), SALIH, Ruba, Musulmane Rivelate, Donne Islam e Modernità, Carocci, Roma.

(2012) SIEBERT, Renate, Voci e Silenzi Post-coloniali. Frantz Fanon, Assia Djebar e noi, Carocci, Roma.

(1995) TRIBALAT, Michèle, Faire France. Une enquête sur les immigrés et leurs enfants, La Découverte, Paris.

(2009) VENTURA, Alberto, "Il Mondo Islamico Contemporaneo e la Costruzione di una Nuova Identità". In FILORAMO, Giovanni and TOTTOLI Roberto (Eds), Le Religioni e il Mondo Moderno, Einaudi, Torino, pp 203- 213. 
(1973) WILLIAMS, Raymond, 'Base and Superstructure in Marxist Cultural Theory', New Left Review 1, 82, pp 3- 16. 